Ambient Science, 2020: Vol. 07(Sp1); 64-69

DOI:10.21276/ambi.2020.07.sp1.oa07

\title{
Analysis of the Relationship Between Multiple Leadership Orientations and Social Intelligence Levels of Students at Faculty of Sports Sciences
}

\section{Fatih Dinç, Ahmet Erdi Avanoglu}

Niğde Ömer Halisdemir University, Faculty of Sports Sciences

Study Area: Corum, Turkey

Coordinates: $40^{\circ} 33^{\prime}$ oo? $34^{\circ} 57^{\prime} 14$ ?E

Keywords: Sports Management, Teaching, Coaching

\section{Introduction:}

Sports has been a social and social element today. Being among the largest industries in the world, together with being a necessity of healthy life, sports has become an area where nations and states show up. At this point, it can be said that sports organizations need leadership as well as having a good athlete in achieving success in sports. People who train, direct, manage and coach athletes are called leaders. Leaders influence and motivate athletes in achieving the determined goals and objectives while carrying out these activities, and at the same time increase their relations with the group (Dogan, 2005). According to Eren and Güner, leader is the coach, team captain or club manager for the player, and physical education and sports teaching for the student. Thus, it could be said that there is a close relationship between the leader and sports in people's minds in order for athletes to display their performance at the highest level and to create team spirit. Leadership in sports is significantly effective for success (Turan et al., 2016). Following another point of view, leadership is the person or team holding the first place in the competition (Bostanci, 2011; Gökçe, 2014).

As per literature, the concept of leadership can be expressed as a person who persuades people, enables people to use all their capacities to reach their goals, manages and builds a team (Arslan \& Uslu, 2014). Bolman \& Deal (1991) stated that when defining leadership

\section{Abstract}

Total 950 students studying at the Faculty of Sport Sciences were selected for tyhe study and data were collected by scanning model, one of the quantitative research methods. As a data collection tool, the "Multidimensional Leadership Orientations Scale" and the "Tromso Social Intelligence Scale" were used. Descriptive statistics were made in the analysis of the data, and nonparametric analyzes were applied because the data did not see a normal distribution. Since the relationship was wanted to be looked at in the research, the Spearman test was used among correlation analysis. Finally we found there were significant relationships between the sub-dimensions of the scales. Significant relationships were found between leadership orientations and social skill levels in general subdimensions of family monthly income, department, mother education level and father education level.

orientations, leaders reveal their own methods and use them in problem solving. When the leadership orientations are examined, it can be said that there are basically four leadership orientations. These are structure oriented leadership, people oriented leadership, political leadership and charismatic leadership. According to Dereli (2003), leadership towards structure is the leadership orientation that attaches importance to the problems in a rational, realistic and detailed way, and holds individuals responsible for the problems encountered. Leadership towards people is the leadership orientation that highlights the human factor that gives importance to the individuals working in the group. Political leadership is deliberative leadership orientation with high persuasiveness while the charismatic leadership is the leadership orientation that inspires environment.

It can be mentioned that the students of the faculty of sports sciences should have social skills for leadership. The main reason for this is that students who play sports in many different branches are in constant contact with the school, teammates, coaches and managers due to the socialization that exists in a sport-specific structure. Therefore, it can be said that university students who are interested in sports also need social skills (Erdoğan et al., 2014).

It can be said that social intelligence is one of the most important factors in the individual's ability to understand, internalize and adapt to himself and the social relations

*Corresponding Author: fatihdinc33@gmail.com 
around him (Lathesh \& Vidya, 2018). It is known that the first studies on social intelligence, which is defined as the art of understanding and managing people and the ability to behave skillfully in human relations, were made by Thorndike in 1920 (Refer: Doğan \& Çetin, 2008). Social intelligence, in the individual's relations with his environment, is def ined as the openness of the relationship, the emotional bonding, the ability to collaborate and the ability to social interaction (Albretch, 2006). According to Vernon (1933), social intelligence is the capacity of individuals to get along well among themselves and with group members, the freedom and knowledge of social issues created by people's trust and respect for each other. According to Gardner (1983), social intelligence is the understanding of other people's moods, motivations, characters, feelings, and desires, and choosing the right behavior when reacting to them. It can be said that individuals who are capable of analyzing character and personalities in understanding human behavior have social intelligence.

As sports are physically and psychologically beneficial, it can be said that one of the most important differences it creates for people doing active sports is socialization. According to Ikizler (2000), the socialization processes of individuals who regularly participate in sports are quite fast. In contemporary societies, it is inevitable that sports are mostly a collective activity and individuals who are interested in sports are in social relations with different human communities that they affect or are affected through sports activities (Yetim, 2005). The communication of a football player with his team while learning the rules of the game can be defined as social intelligence (Bümen, 2004). In essence, physical education and sports help people to socialize and join a group by communicating with each other, while opening the doors to a healthy life through physical activities (Küçük \& Koç, 2004).

By considering the above we aimed to examine the relationship between the multiple leadership orientations and social intelligence of physical education and sports teaching, coaching and sports manager candidates studying at the faculty of sports sciences.

\section{Methodology:}

We conducted a descriptive and quantitative type of study and was in a relational survey model. The universe of this study was conducted on Nigde Ömer Halisdemir University students. The sample was the students of the Faculty of Sport Sciences. 950 students are being educated in the faculty and data were reached to 203 students by random method.

With the personal information form, the multidimensional leadership orientations scale developed by Dursun et al., (2019) and the Tromso Social Intelligence scale developed by Silvera et al., (2001), translated into Turkish by Dogan \& Çetin (2009) were used.
The data obtained in the study were transferred to the SPSS 22.0 package program and the necessary statistical processes were applied. Percentage frequency analysis of the descriptive information of the participants was made. Normality tests of measurement groups and variables were conducted. As a result of normality tests, nonparametric tests were applied to the data that did not show a normal distribution, and the Spearman test was used to determine the relationship. The significance level of the study was accepted as $\mathrm{p}<0.05$.

\section{Results:}

It has been observed that all sub-dimensions of the multidimensional leadership orientations scale (MLOS) of the participants with a monthly income of $2000 \mathrm{TL}$ or less have a positive significant relationship between social knowledge process and social skills.

There was a moderately positive significant correlation between social knowledge process and social skills of all MLOS sub-dimensions of those with an income between $2001 \mathrm{TL}-3000 \mathrm{TL}$. It was determined that there is a positive and significant relationship between political leadershipand social awareness.

In addition, a moderate positive significant relationship was determined between the political leadership and charismatic leadership and social knowledge process of the ones between 3001 TL - 5000 TL. A positive significant relationship was determined between human-induced leadership, charismatic leadership and structural leadership and social knowledge process of the participants of $5000 \mathrm{TL}$ and above. In addition, a moderately positive significant relationship was found between the political leadership and all the TSIS subdimensions of the $2001 \mathrm{TL}-3000 \mathrm{TL}$ (Table 1 ).

A moderately positive significant relationship was found between the political leadership and all subdimensions of the Tromso social intelligence scale (TSIS) of the students in the physical education teacher candidate group. A moderately positive significant relationship was found between all the sub-dimensions of MLOS and the social knowledge process of the same group.

There was a low level of positive and significant relationship between human-based leadership and social knowledge process in the coach training group. A moderate positive and significant relationship was observed between the political and charismatic leadership of the participants and the social knowledge process.

A moderately positive significant correlation was observed between all the sub-dimensions of MLOS and social knowledge process in the sports management group. A positive and significant relationship was found between the political, human-based and charismatic leadership and social skills of the participants (Table-2).

A moderately positive significant relationship was found between all sub-dimensions of the 
Table 1. Interrelationships of scale sub-dimensions on family monthly income (Social Intelligence Scale Sub-Dimensions)

\begin{tabular}{|c|c|c|c|c|c|c|c|c|c|c|}
\hline \multirow{2}{*}{$\begin{array}{l}\text { Family Monthly } \\
\text { Income (TL) }\end{array}$} & \multirow{2}{*}{$\begin{array}{l}\text { MLOS } \\
\text { Sub-Dimension }\end{array}$} & \multicolumn{3}{|c|}{ Social Info. Process } & \multicolumn{3}{|c|}{ Social Skills } & \multicolumn{3}{|c|}{ Social Awareness } \\
\hline & & $\mathrm{n}$ & $\mathrm{r}$ & $\mathrm{p}$ & $\mathrm{n}$ & $r$ & $\mathrm{p}$ & $\mathrm{n}$ & $\mathrm{r}$ & $\mathrm{p}$ \\
\hline \multirow[t]{4}{*}{2000 TL and less } & Politic & 62 & $0.50^{* *}$ & 0.00 & 62 & $0.34^{* *}$ & 0.01 & 62 & 0.04 & 0.74 \\
\hline & Human Based & 62 & $0.53^{* *}$ & 0.00 & 62 & $0.39^{* *}$ & 0.00 & 62 & 0.09 & 0.48 \\
\hline & Charismatic & 62 & $0.43^{* *}$ & 0.00 & 62 & $0.31^{*}$ & 0.02 & 62 & -0.10 & 0.43 \\
\hline & Structural & 62 & $0.46^{* *}$ & 0.00 & 62 & $0.35^{* *}$ & 0.01 & 62 & 0.07 & $0.5^{8}$ \\
\hline \multirow[t]{4}{*}{ 20001- $3000 \mathrm{TL}$} & Politic & 84 & $0.41^{* *}$ & 0.00 & 84 & $0.44^{* *}$ & 0.00 & 84 & $0.30^{* *}$ & 0.01 \\
\hline & Human Based & 84 & $0.42^{* *}$ & 0.00 & 84 & $0.25^{*}$ & 0.02 & 84 & 0.15 & 0.18 \\
\hline & Charismatic & 84 & $0.50^{* *}$ & 0.00 & 84 & $0.23^{*}$ & 0.04 & 84 & 0.07 & 0.50 \\
\hline & Structural & 84 & $0.42^{* *}$ & 0.00 & 84 & $0.24^{*}$ & 0.03 & 84 & 0.16 & 0.15 \\
\hline \multirow[t]{4}{*}{ 3001- $5000 \mathrm{TL}$} & Politic & 37 & $0.41^{*}$ & 0.01 & 37 & -0.09 & 0.59 & 37 & 0.05 & 0.76 \\
\hline & Human Based & 37 & $0.35^{*}$ & 0.04 & 37 & -0.15 & 0.37 & 37 & -0.06 & 0.74 \\
\hline & Charismatic & 37 & $0.41^{*}$ & 0.01 & 37 & 0.14 & 0.41 & 37 & 0.10 & 0.57 \\
\hline & Structural & 37 & 0.15 & 0.38 & 37 & -0.14 & 0.42 & 37 & -0.27 & 0.11 \\
\hline \multirow{4}{*}{50001 TL \& more } & Politic 20 & 0.37 & 0.11 & 20 & 0.06 & 0.80 & 20 & 0.25 & 0.30 & \\
\hline & Human Based & 20 & $0.65^{* *}$ & 0.00 & 20 & 0.11 & 0.65 & 20 & -0.06 & 0.79 \\
\hline & Charismatic & 20 & $0.52^{*}$ & 0.02 & 20 & 0.07 & 0.76 & 20 & 0.05 & 0.85 \\
\hline & Structural & 20 & $0.51^{*}$ & 0.02 & 20 & 0.04 & 0.87 & 20 & -0.08 & 0.72 \\
\hline
\end{tabular}

${ }^{* *} \mathrm{p}<0.01 /{ }^{*} \mathrm{p}<0.05 /$ MLOS: Multiple Leadership Orientations Scale

Table 1. Mutual relations of scale sub-dimensions from the department variable (Social Intelligence Scale Sub-Dimensions)

\begin{tabular}{|c|c|c|c|c|c|c|c|c|c|c|}
\hline \multirow[t]{2}{*}{ Department } & \multirow{2}{*}{$\begin{array}{l}\text { MLOS } \\
\text { Sub-Dimension }\end{array}$} & \multicolumn{3}{|c|}{ Social Info. Process } & \multicolumn{3}{|c|}{ Social Skills } & \multicolumn{3}{|c|}{ Social Awareness } \\
\hline & & $\mathrm{n}$ & $\mathrm{r}$ & $\mathrm{p}$ & $\mathrm{n}$ & $\mathrm{r}$ & $\mathrm{p}$ & $\mathrm{n}$ & $\mathrm{r}$ & $\mathrm{p}$ \\
\hline Physical Training & Politic & 63 & $0.43^{* *}$ & 0.00 & 63 & $0.46^{* *}$ & 0.00 & 63 & $0.46^{* *}$ & 0.00 \\
\hline \multirow{3}{*}{ Teacher Cand. } & Human Based & 63 & $0.42^{* *}$ & 0.00 & 63 & 0.14 & 0.27 & 63 & -0.01 & 0.92 \\
\hline & Charismatic & 63 & $0.59^{* *}$ & 0.00 & 63 & 0.23 & 0.07 & 63 & 0.23 & 0.07 \\
\hline & Structural & 63 & $0.49^{* *}$ & 0.00 & 63 & $0.38^{* *}$ & 0.00 & 63 & 0.21 & 0.10 \\
\hline Coach Training & Politic & 46 & $0.38^{*}$ & 0.01 & 46 & -0.04 & 0.77 & 46 & -0.09 & 0.55 \\
\hline \multirow[t]{3}{*}{ Candidate } & Human Based & 46 & $0.58^{* *}$ & 0.00 & 46 & 0.06 & 0.67 & 46 & 0.12 & 0.43 \\
\hline & Charismatic & 46 & $0.37^{*}$ & 0.01 & 46 & -0.19 & 0.21 & 46 & -0.24 & 0.11 \\
\hline & Structural & 46 & 0.16 & 0.28 & 46 & -0.14 & 0.37 & 46 & -0.22 & 0.14 \\
\hline Sports Manager & Politic & 94 & $0.48^{* *}$ & 0.00 & 94 & $0.31^{* *}$ & 0.00 & 94 & 0.17 & 0.11 \\
\hline \multirow[t]{3}{*}{ Candidate } & Human Based & 94 & $0.45^{* *}$ & 0.00 & 94 & $0.28^{* *}$ & 0.01 & 94 & 0.07 & 0.53 \\
\hline & Charismatic & 94 & $0.46^{* *}$ & 0.00 & 94 & $0.40^{* *}$ & 0.00 & 94 & 0.08 & 0.47 \\
\hline & Structural & 94 & $0.44^{* *}$ & 0.00 & 94 & 0.18 & 0.08 & 94 & 0.10 & 0.35 \\
\hline
\end{tabular}

Table-3: The correlations between the sub-dimensions of the scale on the mother education level

\begin{tabular}{|c|c|c|c|c|c|c|c|c|c|c|}
\hline \multirow{2}{*}{$\begin{array}{l}\text { Mother } \\
\text { Education }\end{array}$} & \multirow{2}{*}{$\begin{array}{l}\text { MLOS } \\
\text { Sub-Dimension }\end{array}$} & \multicolumn{3}{|c|}{ Social Info. Process } & \multicolumn{3}{|c|}{ Social Skills } & \multicolumn{3}{|c|}{ Social Awareness } \\
\hline & & $\mathrm{n}$ & $\mathrm{r}$ & $\mathrm{p}$ & $\mathrm{n}$ & $\mathrm{r}$ & $\mathrm{p}$ & $\mathrm{n}$ & $\mathrm{r}$ & $\mathrm{p}$ \\
\hline \multirow[t]{4}{*}{ Primary } & Politic & 128 & $0.42^{* *}$ & 0.00 & 128 & $0.21^{*}$ & 0.02 & 128 & 0.13 & 0.16 \\
\hline & Human Based & 128 & $0.49^{* *}$ & 0.00 & 128 & $0.24^{* *}$ & 0.01 & 128 & 0.09 & 0.32 \\
\hline & Charismatic & 128 & $0.47^{* *}$ & 0.00 & 128 & $0.18^{*}$ & 0.04 & 128 & -0.02 & 0.82 \\
\hline & Structural & 128 & $0.40^{* *}$ & 0.00 & 128 & 0.15 & 0.10 & 128 & 0.05 & 0.54 \\
\hline \multirow[t]{4}{*}{ Secondary } & Politic & 47 & $0.49^{* *}$ & 0.00 & 47 & $0.53^{*}$ & 0.00 & 47 & $0.38^{* *}$ & 0.01 \\
\hline & Human Based & 47 & $0.39^{* *}$ & 0.01 & 47 & 0.24 & 0.11 & 47 & 0.04 & 0.77 \\
\hline & Charismatic & 47 & $0.43^{* *}$ & 0.00 & 47 & $0.33^{*}$ & 0.02 & 47 & 0.13 & 0.38 \\
\hline & Structural & 47 & $0.32^{*}$ & 0.03 & 47 & $0.37^{*}$ & 0.01 & 47 & 0.18 & 0.22 \\
\hline \multirow[t]{4}{*}{ High School } & Politic & 23 & 0.34 & 0.11 & 23 & -0.01 & 0.98 & 23 & 0.18 & 0.40 \\
\hline & Human Based & 23 & $0.62^{* *}$ & 0.00 & 23 & 0.07 & 0.76 & 23 & 0.21 & 0.35 \\
\hline & Charismatic & 23 & $0.49^{*}$ & 0.02 & 23 & 0.24 & 0.27 & 23 & $0.46^{*}$ & 0.03 \\
\hline & Structural & 23 & $0.42^{*}$ & 0.05 & 23 & 0.08 & 0.73 & 23 & 0.06 & 0.77 \\
\hline \multirow[t]{4}{*}{ University } & Politic & 5 & -0.73 & 0.17 & 5 & -0.71 & 0.18 & 5 & 0.00 & 1.00 \\
\hline & Human Based & 5 & -0.06 & 0.93 & 5 & -0.34 & 0.58 & 5 & -0.86 & 0.06 \\
\hline & Charismatic & 5 & -0.65 & 0.24 & 5 & $-0.95^{*}$ & 0.01 & 5 & -0.73 & 0.16 \\
\hline & Structural & 5 & -0.70 & 0.19 & 5 & -0.63 & 0.25 & 5 & -0.89 * & 0.04 \\
\hline
\end{tabular}


Ambient Science, 2020: Vol. 07(Sp1); 64-69

DOI:10.21276/ambi.2020.07.sp1.oa07

Table 4. The mutual relations of the scale sub-dimensions from the father education level variable

\begin{tabular}{|c|c|c|c|c|c|c|c|c|c|c|}
\hline \multirow{2}{*}{$\begin{array}{l}\text { Father } \\
\text { Education }\end{array}$} & \multirow[t]{2}{*}{ MLOS } & \multicolumn{3}{|c|}{ Social Info. Process } & \multicolumn{2}{|c|}{ Social Skills } & \multirow[b]{2}{*}{$\mathrm{r}$} & \multicolumn{3}{|c|}{ Social Awareness } \\
\hline & & hension & $\mathrm{n}$ & $\mathrm{r}$ & $\mathrm{p}$ & $\mathrm{n}$ & & $\mathrm{p}$ & $\mathrm{n}$ & rp \\
\hline \multirow[t]{4}{*}{ Primary } & Politic & 87 & $0.40^{* *}$ & 0.00 & 87 & $0.25^{*}$ & 0.02 & 87 & 0.12 & 0.27 \\
\hline & Human Based & 87 & $0.42^{* *}$ & 0.00 & 87 & $0.25^{*}$ & 0.02 & 87 & 0.09 & 0.41 \\
\hline & Charismatic & 87 & $0.43^{* *}$ & 0.00 & 87 & $0.29^{* *}$ & 0.01 & 87 & 0.06 & 0.60 \\
\hline & Structurall & 87 & $0.30^{* *}$ & 0.00 & 87 & 0.19 & 0.08 & 87 & 0.06 & 0.59 \\
\hline \multirow[t]{4}{*}{ Secondary } & Politic & 53 & $0.44^{* *}$ & 0.00 & 53 & $0.37^{* *}$ & 0.01 & 53 & 0.20 & 0.15 \\
\hline & Human Based & 53 & $0.48^{* *}$ & 0.00 & 53 & 0.22 & 0.12 & 53 & -0.06 & 0.67 \\
\hline & Charismatic & 53 & $0.43^{* *}$ & 0.00 & 53 & 0.17 & 0.22 & 53 & -0.08 & 0.56 \\
\hline & Structural & 53 & $0.50^{* *}$ & 0.00 & 53 & $0.37^{* *}$ & 0.01 & 53 & 0.19 & 0.17 \\
\hline \multirow[t]{4}{*}{ High School } & Politic & 45 & $0.45^{* *}$ & 0.00 & 45 & 0.21 & 0.16 & 45 & $0.37^{*}$ & 0.01 \\
\hline & Human Based & 45 & $0.52^{* *}$ & 0.00 & 45 & 0.21 & 0.17 & 45 & 0.19 & 0.22 \\
\hline & Charismatic & 45 & $0.48^{* *}$ & 0.00 & 45 & 0.21 & 0.17 & 45 & 0.16 & 0.30 \\
\hline & Structural & 45 & $0.34^{*}$ & 0.02 & 45 & 0.08 & 0.60 & 45 & -0.06 & 0.68 \\
\hline \multirow[t]{2}{*}{ University } & Politic & 18 & 0.35 & 0.16 & 18 & 0.20 & 0.42 & 18 & 0.19 & 0.46 \\
\hline & Human Based & 18 & $0.50^{*}$ & 0.03 & 18 & -0.12 & 0.65 & 18 & -0.17 & 0.50 \\
\hline
\end{tabular}

Multidimensional Leadership Orientation Scale (MLOS) and the social knowledge process of the mother education level primary school group. There was a low level of positive and significant relationship between the politic, humanbased and charismatic leadership and social skills of the samegroup.

A moderately positive significant relationship was found between the politic leadership and all subdimensions of TSIS of those whose mother's education level was secondary school. In addition, a moderate positive significant relationship was found between politic and charismatic leadership and social knowledge process. There is a weak positive and significant relationship between human-based and structural leadership and social knowledge process. A weak positive significant relationship was observed between charismatic and structural leadership and social skills.

A moderately positive significant relationship was observed between charismatic, human-based and structural leadership and social knowledge process of those whose mother's education level was high school. A moderately positive significant relationship was observed between charismatic leadership and social awareness.

A highly significant negative relationship was found between charismatic leadership and social skills of those whose mother's education level is university. In the same group, a highly significant negative relationship was observed between structural leadership and social awareness (Table-3).

A moderate positive significant relationship was observed between the politic, human-based and charismatic leadership and the social knowledge process of the primary school group of the father's education level. In the same group, a low-grade positive significant relationship was observed between structural leadership and social knowledge process. There was a low level positive signif icant relationship between politic, human-based and charismatic leadership and social skills.

A moderately positive significant relationship was observed between all MLOS sub-dimensions and the social knowledge process of the father's education level secondary school group. A weak positive significant relationship was observed between politic leadership, structural leadership and social skills.

There was a moderately positive significant relationship between the politic leadership, human-based leadership, charismatic leadership and social knowledge process of the father education level high school group. There is a weakly positive and significant relationship between structural leadership and social knowledge process. In addition, there was a weakly positive and significant relationship between politic leadership and social awareness.

A positive significant relationship was observed between the human-based leadership, charismatic leadership and the social knowledge process of the university group for father's education level (Table-4).

\section{Results and Discussion:}

In this study, statistically positive significant relationships were found between the multi-dimensional leadership orientations and social intelligence of the participants on the family monthly income variable. A moderate meaningful relationship was found between politic, human-based, charismatic and structural leadership and social knowledge process of groups between $2000 \mathrm{TL}$ and less, $2001 \mathrm{TL}-3000 \mathrm{TL}, 3001 \mathrm{TL}-5000 \mathrm{TL}$. In groups with an income of $5000 \mathrm{TL}$ and more, high in human-based leadership, a moderate relationship between charismatic leadership and structural leadership and social knowledge process has been determined. Tapsin et al., (2020) state in their study that the structure-oriented and charismatic leadership orientations of the individuals who coach are affected by the economic situation and that their leadership characteristics are related to income. It can be said that this 
situation is similar to our findings of structural and charismatic leadership orientations. A weakly significant relationship was observed between the multidimensional leadership orientation sub-dimensions and their social skills of the groups between 2000 TL and less, 2001 TL - 3000 TL. Senol (2015) did not find a statistically significant difference between the income level and social skills in the findings obtained from students studying physical education teaching in his study is similar to our study. However, in the Çiris (2018) study, the increase in social skills as the income level increases contradicts our study.

From the findings of our study, it can be said that in groups with high monthly family income, they are effective in using social information processes but ineffective in conducting social skills. However, it can be said that they are effective in conducting social information processes and social skills in groups with low monthly family income. It can be thought that the students of the faculty of sports sciences are individuals who do sports and communicate with their environment. In addition, it can be said that the effect of the family economical situation on the leadership orientation of the students of sports sciences faculty and their social intelligence is not high.

In general, positive significant relationships were found between the multidimensional leadership behaviors and their social intelligence through the department variable. In the studies of Cengiz \& Güllü (2018), that the leadership orientations according to the department did not differ signif icantly is partially parallel with the findings of our study. Similarly, Sezer \& Kahraman (2018), stated the fact that teacher candidates' charismatic, human-based, transformational and structural leadership did not differ according to the departments they studied in supports our study's finding. In all of the leadership orientations of the teaching and sports management students, positive significant relationships were found with the social knowledge process. A weak but positive significant relationship was found between politic and charismatic leadership and social knowledge process in the groups studying the coaching education department. On the other hand, there is a moderate positive significant relationship between human-based leadership and social information process. That the leadership orientations in their study by Arslan \& Uslu (2014) found a signif icant difference in favour of foreign language teacher candidates according to the department is similar to our study. On the other hand, Turan et al., (2016) understood that the leadership levels of physical education and sports teaching students significantly predicted their attitudes towards the profession and the sub-dimensions of human and charismatic leadership. In the literature, there are studies that are similar to the finding of our study (Aydin, 2016; Hayri, 2010; Öztürk, 2017; Eryücel 2018). In our study, a significant positive relationship was found between the leadership orientations of the participants and their social intelligence in general. This finding can be thought due to the fact that the research group consists of students of the faculty of sports sciences, all of whom do sports and make sports a part of their lives and are intertwined with society.

A statistically significant positive relationship was found between the sub-dimensions of multidimensional leadership orientations behaviours and social intelligence sub-dimensions on the mother education level variable. A moderately positive significant relationship was found between all leadership orientations of the groups with a mother's education level and the social knowledge process. In the study conducted by Turhal (2019), no significant difference was found between social intelligence and maternal education level. This result partially supports our findings. Again, in the same study of the researcher, finding a significant difference between leadership orientations and maternal education level seems to partially support our findings. According to this result, it can be said that the students of the faculty of sports sciences are people who have more comfortable social relationships and have higher social awareness due to their being related to sports.

On the father education level variable, statistically significant positive relationships were found between the sub-dimensions of multiple leadership orientation behaviours and social intelligence sub-dimensions. In the study conducted by Turhal (2019), it was observed that a significant difference was detected between leadership orientations and those whose father's education level was high school. In the same study conducted by the researcher, a significant difference was mentioned between those whose father's education level was university and their social intelligence. It can be said that this finding of the researcher is similar to the results obtained from our study. As a result; The fact that sports sciences faculty students move together with crowded groups while performing sports activities, and a continuous flow of information between them may contribute positively to the social knowledge process. Therefore, it can be said that there is a positive and significant relationship between multidimensional leadership orientations and social intelligence.

\section{References:}

Albretch, K. (2006): Social Intelligence: The New Science of Success. Pub. by: John Wiley \& Sons, San Francisco. P 289.

Altun, B. \& Sarpkaya, R. (2017): Egitim yönetiminde politik modeller. Adnan Menderes Üniversitesi Egitim Fakültesi Egitim Bilimleri Dergisi, 8(2):1-12.

Arslan, H. \& Uslu, B. (2014): Ögretmen adaylarinin liderlik yönelimlerinin incelenmesi.e-Int. J. Edu. Res., 5(1):42-6o.

Arslan, H. \& Uslu, B. (1991): Ögretmen Adaylarinin Liderlik Yönelimlerinin Incelenmesi. Int. J. Edu. Res., 5(1):42-6o.

Aydin, R. (2016): Beden egitimi ve spor yüksekokullarinda egitim gören bireysel ve takim sporlariyla ugrasan ögrencilerin liderlik özelliklerinin karsilastirilmasi. 
Yüksek Lisans Tezi, Bartin Üniversitesi, Egitim Bilimleri Enstitüsü, Bartin.

Bolman, L.G. \& Deal, T.G. (1991): Reframing organizations. Artistry, choice and leadership. Pub. by: John Wiley \& Sons. San Francisco, P 544 .

Bostanci, A.B. (2011): Sinifta iliski düzenini olusturmada ögretmenin liderligi. Gülsen, C. (Ed.) Kuram ve Uygulamada Sinif Yönetimi. Pub. by: Ani Yayincilik, Ankara, Turkey

Bümen, N.T. (2004): Okulda Çoklu Zekâ Kurami. Pub. by: Pegem A Yayincilik, Ankara.

Çiris, V. (2018): 11. \& 12. Sinif Ögrencilerinin Sosyal Beceri Düzeylerinin Liderlik Özelliklerine Etkisinin Spor Yapma Durumu Açisindan Incelenmesi, (Doktora tezi). Sakarya. Sakarya Üniversitesi Beden Egitimi ve Spor Egitimi Anabilim Dali.

Dereli, M. (2003): A survey research of leadership styles of elementary school principles. Yayinlanmamis yüksek lisans tezi. Pub. by: Orta Dogu Teknik Üniversitesi, Egitim Fakültesi, Ankara, Turkey.

Dogan, O.(2005): Spor Psikolojisi (2.Baski). Adana. Nobel, 70.

Dogan, T. \& Çetin, B. (2008): Üniversite Ögrencilerinin Sosyal Zeka Düzeylerinin Depresyon ve Bazi Degiskenlerle Iliskisinin Incelenmesi. Uluslararasi Insan Bilimleri Dergisi, 5(2):1-19.

Dogan, T. \& Çetin, B. (2009): Tromso sosyal zekâ ölçegi Türkçe formunun faktör yapisi, geçerlik ve güvenirlik çalismasi. $\underline{E d u}$. Sci.: Theory Prac., 7(1):241-268.

Dursun, M., Günay, M. \& Yenel, I.F. (2019): Çok Yönlü Liderlik Yönelimleri Ölçegi (ÇYLYÖ): Geçerlik ve Güvenirlik Çalismasi. Uluslararasi Yönetim Akademisi Dergisi, 2(2):333347.

Erdogan, E., Sözen, H. \& Cevahiroglu, B. (2014): Farkli Spor Bransindaki Üniversite Ögrencilerinin Sosyal Beceri Düzeylerinin Belirlenmesi. Uluslararasi Sosyal Arastirmalar Dergisi, 7(33):828-834.

Eren, E. (2001): Yönetim ve Organizasyon. Pub. by: Beta Basim Yayim, Ankara, Turkey.

Eryücel, M.E. (2018): Spor Egitimi Alan Üniversite Ögrencilerinin Liderlik Özelliklerinin Belirlenmesi. Elect. Turk. Stud., 13(11).

Gardner, H. (1983): Frames of mind the theory of multiple intelligences. Pub. by: Basic Books, NYC.

Gnanadevan, R. (2007): Social intelligence of higher secondary students in relation to their socioeconomic status. L. Comm. Guid. Res., 24(3):340-346.

Gökçe, F. (2014): Sinifta ögrenme ve ögretme sürecinin yönetimi. Pub. by: Pegem Akademi, Ankara, Turkey.

Güner, S. (2002): Dönüsümsel Liderligin Güç Kaynaklari ve Silahli Kuvvetler Organizasyonunun Dönüsümsel Liderlige Uygunluk Açisindan Degerlendirilmesi. Yayinlanmamis Yüksek Lisans Tezi, SDÜ Sosyal Bilimler Enstitüsü, Isparta
Hayri, Y. (2010): Ilkögretim Okulu Yöneticilerini Liderlik Yönelimleri ve Mesleki Etik Algilari Arasindaki Iliskiler: Ilkögretim Ögretmenleri Örnekleminde Iliskisel Bir Çalisma. Yüksek Lisans. Yeditepe Üniversitesi Sosyal Bilimler Enstitüsü, Istanbul.

Ikizler, H.C. (200o): Sporda Sosyal Bilimler. Pub. by: Alfa Basin Yayim Dagitim, Istanbul, Turkey.

Küçük, V. \& Koç, H. (2004): Psiko-sosyal gelisim süreci içerisinde insan ve spor iliskisi. Dumlupinar Üniversitesi Sosyal Bilimler Dergisi, 9(1):211-223.

Lathesh, K.R. \& Vidya D.A. (2018): A Study on Social Intelligence and its Impact on Employee Performance of Insurance Sectors in Mysuru City. Int. J. Mech. Eng. Technol., 9(1):530537.

Öztürk, K.E. (2017): Beden Egitimi Ve Spor Yüksekokulu Ögrencilerinin Liderlik Yönelimleri ve Öz Güven Davranislarinin Incelenmesi. Yüksek Lisans Tezi, Inönü Üniversitesi Saglik Bilimleri Enstitüsü, Malatya.

Sezer, G.O. \& Kahraman, P.B. (2018): Ögretmen Adaylarinin Liderlik Yönelimlerinin Çesitli Degiskenler Açisindan Incelenmesi. Kastamonu Edu. J., 26(5):1551-156o.

Senol, E. (2015): Beden Egitimi ve Spor Ögretmenligi Ile Egitim Fakültesi Sinif Ögretmenlerinin Sosyal Beceri Düzeylerinin Incelenmesi. Yüksek Lisans Tezi. Kahramanmaras, Kahramanmaras Sütçü Imam Üniversitesi, SBE.

Tapsin, F.O., Bayazit, B., Aydemir, A. \& Tapsin, F.O. (2020): Bireysel ve Takim Sporlarindaki Antrenörlerin Liderlik Davranislari Yönelimlerinin Bazi Degiskenlere Göre Belirlenmesi (Sakarya Ili Adapazari Ilçesi Örnegi). Elect. Turk. Stud., 15(5).

Turan, M.B., Erol, Z. \& Karaoglu, B. (2016): Beden egitimi ve spor ögretmenligi bölümünde okuyan ögrencilerin liderlik düzeylerinin ögretmenlik meslegi yordama gücünün incelenmesi. Spor Bilimleri Dergisi, 6(3):71-78.

Turan, M.B., Erol, Z. \& Karaoglu, B. (2016): The analysis of predictive power on teaching profession's features of attitude and students' levels of leadership in school of physical education and sports. Istanbul Üniversitesi Spor Bilimleri Dergisi, 6(3):1303-1414.

Turhal, S.N. (2019): Sporyöneticisi adaylarinin liderlik yönelimleri ve sosyal zekâ düzeyleri arasindaki iliskinin incelenmesi (Master's thesis, Bursa Uludag Üniversitesi).

Vernon, P.E. (1933): Some characteristics of the good judge of personality.J.Soc. Psychol., 4(1):42-57.

Yetim, A. (2005): Sosyoloji ve spor. Pub. by: Topkar Matbaacilik, Trabzon, Turkey. 